\title{
PROMOTING LESSON STUDY AT ENGLISH FOR SPECIFIC PURPOSES (ESP): TEACHER'S BEST PRACTICE CONTEXT
}

\author{
Masyhud $^{1}$ \\ English Language Education Department, University of Muhammadiyah Malang- Indonesia ${ }^{1}$ \\ e-mail: Masyhud863@umm.ac.id
}

\begin{abstract}
English for Specific Purposes (ESP) is an exciting movement in language education. It widens the opportunities for English teachers and researchers to explore the curriculum, course planning and implementation of ESP education. However, there are several problems in teaching ESP. one of the most problems is students' engagement in the class because they felt learning English unrelated to their major. Therefore, this research concerns to investigate the implementation of Lesson Study in Teaching English for Specific Purposes (ESP) to sharpen the students' critical thinking. Lesson Study has been a precious motion for recent decades, principally for the sake of teachers' professional development and students' critical thinking. This research involved 5 ESP teachers. They acquired equal chance to be a teacher model and observer in the LS process. This research conducted in 2 cycles with three phases; Plan, Do, and See. This research employed observation and document analysis as the tools to collect the data. This Lesson study was implemented into two stages, planning and implementation. However, it can encourage the students to participate actively along the learning process because cycle $1 \mathrm{can}$ provide student's participation $90 \%$ and in cycle $2,95 \%$ of students involved in the learning process.
\end{abstract}

Keywords: Lesson study, English for specific purposes

\section{Introduction}

English for Specific Purposes (ESP) always become remarkable motion in language learning. It widens the opportunities for English teachers and researchers to explore the curriculum, course planning and implementation of ESP education and its impact on learners (Hsu, 2014). Moreover, globalization leads learners to enter professions, focusing on the language of academic performance in specific discourse communities (sometimes preparing for near-future identified workplace needs) in the fields of Business, Engineering, Medicine, Information Technology, Law, etc. (Candel-mora, 2015). Therefore, the existence of ESP put significant role in education. The teacher must meet the student's need and profession based on their field in the future

Students learn English is not merely to develop their language proficiency, but also to gain specific skill which can perform the language in their major of their studies. In other words, students need for ESP is further advocated all those students who have learned English for Specific Purposes during their studies, would help them simply to fit in to their work atmosphere where most of globalization trends are massively interconnected with the English language capability which will provide accessible skill they employed (Saliu \& Hajrullai, 2016). In addition, Brunton (2009) identifies the development of ESP for certain decades as result of globalization market forces the academic circumstances to accomplish the student's profession. Thus, the ideal ESP 
teachers must not only be skillful in English language, but also acquire the knowledge of a specific profession in order to provide an effective ESP course for the learners.

In addition, ESP is an approach to language learning, which is required on student's needs (Rahman, 2015). It means that ESP is an English course based on the survey result and needs analysis in order to determine the specific activities that students have to do as well as the final goal they have to achieve. Thus, ESP is an English course of which the textbook and materials are adjusted to the learners' desires and purposes.

Besides, Labora \& Litzer (2015) state that ESP must justify the learner's need. It is used to trigger methodology and activities of the discipline it serves, and it is centered on the language appropriate to these activities in terms of grammar, lexis, register, study skills, discourse and gender. It means that it is also a device to support learners in order to construct their awareness of English based on their fields of the study and specific purposes.

ESP requires the teachers to meet the skill which derived from specific student's need. It leads challenges on ESP. A study on the difficulties in learning ESP at Vietnam Universities by Nguyen and Thi (2016) shows that the students face some challenges in ESP as follows: (1) demographic characteristic does not meet the student's demand; (2) ESP students have different level proficiency; (3) their L1 is much different with L2, particularly ESP context; (4) Students' motivation is low; (5) ESP students have limited vocabularies; and (6) ESP teachers' qualification and textbook cannot facilitate the student's interest. The teachers tend to use monotonous method in the class. It causes the students bored and passive in the class. They just listen what the teacher taught without considering the skill which must be mastered. Besides, another concern on ESP is related to environment. Most of ESP classes have big number of students (Suzini, 2011). It means that the classes are not conducive anymore.

In addition, Alameddine (2012) revealed that negative transfer, different writing strategies, propositional knowledge, and collocational pattern are the common problems in learning ESP. Concerning with reading, writing, speaking, and listening skills in ESP, Talepasan (2012) showed that mainly students had difficulties in identifying and understanding syntaxes of sentences, organizing ideas, grammar and spelling, and had very little time of practicing.

Some problems in learning ESP need to be solved in order to achieve the goal of the teaching and learning process. Hence, teachers should provide a good way in teaching ESP, offer an interesting topic, create a conducive classroom atmosphere, plan a variety of teaching and learning activities, and teach the materials effectively. In brief, teachers have a crucial role regarding the successful teaching and learning activities. Therefore, teachers should be able to assist a class atmosphere which can provide solution for the students' problems, obviously in ESP class set. A comprehensive professional development is needed to aid teachers to increase their teaching performance. One of the teacher professional developments is Lesson Study (LS).

LS is a collaborative professional development which is developed the teaching plan together and evaluate the teaching and learning processes together. The basic concept of LS is a comprehensive teachers' development because LS focuses on acquiring the teachings' goal together. LS as well as enable teachers and lecturers regularly widen their teaching through working together with others as colleagues (Armstrong, 2011; Cajkler, Wood, Norton, \& Pedder, 2013). Thus, LS is not a matter of technique or 
teaching method, but it is more about coaching model to train to teach cooperatively. Therefore, all techniques and methods of teaching can be applied in accordance with the needs of the class, students and subject character, or core competence to be attained.

Experts identified, LS since 1870s has been an identical particular classroom action study focused on the teachers' development of knowledge and practice. LS basically was inspired Action-Research as professional development for teachers (Salvador, 2017) by Lesson Study is not merely implemented in Japan as its country but also applied over time in many countries; America, Europe and Asia due to the LS had a positive impact on sharpening teacher quality and learning output (Kanauan \& Inprasitha, 2014). Dudley (2011) classified four major reasons the importance of LS. First, it supports teachers monitoring the pupils' involvement in learning process more comprehensively. Second, it verifies the gap between what teachers' opinion before learning conducted and whilst process. Third, it provides an appropriate approach to pupils' needs. Fourth, it creates learning and teaching community which is supportive and committed to helping learners to achieve their goal in order to establish professional learning dreamed by the teachers.

Many studies of Lesson Study showed significant impact for the betterment of teaching and the student's learning. However, Lesson study for ESP context is rarely monitored. They believe that ESP provides barriers for educators to explore deeper in which make difficulties for certain aspects (Ahmadi \& Rahimi, 2012). Therefore, this research formulates a question how does Lesson study sharpen the students' critical thinking in ESP context?

\section{Method}

This research employed qualitative method to describe the implementation of LS to sharpen the students' critical thinking. In Lesson study, The researcher involved directly in planning the research, conducting the research, collecting the data, analyzing the data, and display the data. Thus, the researcher will actively contribute along this research to improve the teacher's performance collaboratively and sharpen the students' critical thinking. This is the essential of Lesson Study, providing the teachers' professional development and assisting students to improve their critical thinking.

The subject of this research is ESP teachers at Language Centre of University of Muhammadiyah Malang. There are 5 ESP teachers taught in different departments. This research also will focus on teaching listening skill.

The research instruments are observation, interview, questionnaire, and documentation. The researcher will observe and take note in every phase. The researcher also will provide observation template to aid the researcher in collecting the data. The researcher will interview and give questionnaire to ESP teachers and students to know what is their perception and response on Lesson study. Moreover, the researcher will use documentation as the supportive data such as Lesson plan, picture, and video record of the classroom activity.

Furthermore, This Lesson Study will be implemented for four cycles using Stigler and Hiebert procedures (1999) which applied four steps.

1. Defining the problems 
This procedure defined the problem in the learning process such as teacher's challenges, student's challenges, and policy maker challenges. To draw the problems, all team of LS must identify together the problems.

2. Planning the lesson

All team of LS must plan the lesson together in accordance with the identified problems. Comprehensive planning must be assisted to answer the problem faced by students.

3. Teaching the lesson

The plan must be practiced a day before the class. It is intended to find a fixed plan before the teacher model demonstrated the plan.

4. Evaluate the lesson and see the effect

The teacher will share their view of the lesson, then the others relate the problems they found and the teacher's view. They do not focus on the way of teachers teaching, but they concern on the situation happened in the class. However, Juwariah (2013) simplified the procedure into three namely plan, do, and see.

Regarding to Plan phase, LS team collaboratively plan the learning process by determining the team into some roles. First, 1 ESP teachers as the models, each teacher ESP model should make lesson plan for one meeting and implement it, one ESP teacher as moderator, 4 ESP teacher as observers and 1 teacher-student as the documenter. After setting the team into different roles, the team discussed together the lesson preparation to obtain practical input. The last is providing facilities that will be used in the implementation.

The next phase is Do. In this phase, the models implemented the lesson plan according to agreed learning scenarios in the previous phase. However, the observers observe the learning process in accordance with the scenarios. The last phase is See. The team evaluates all the learning processes from the models conveying their impression and problems in their teaching till hearing evaluation and suggestion of all team's member as a note for present teacher model and as an input for the next teacher model in further cycles.

\section{Findings and Discussion}

This Lesson Study intended to provide solution for student's concerns in the class and give best practice for ESP teachers. All phases are required to fulfill the objectives of this program. Therefore, the result should be directed to answer the objectives. To display an organized result, it will be presented in two stages: planning and implementation.

\section{Planning}

This stage aimed to formulate the steps which will be implemented in LS process. It is very essential in conducting LS because it leads to the success of LS. Good preparation will give promising result of LS (Appova, 2018). There were five fundamental plans of this program:

The researcher discussed with the chief of English for Specific Purposes (ESP) teachers at University of Muhammadiyah Malang (UMM) related to the concerns of learning ESP. The chief is a person in charge to manage all components of teaching ESP at UMM. The discussion highly purposed to acquire the problem of learning ESP at

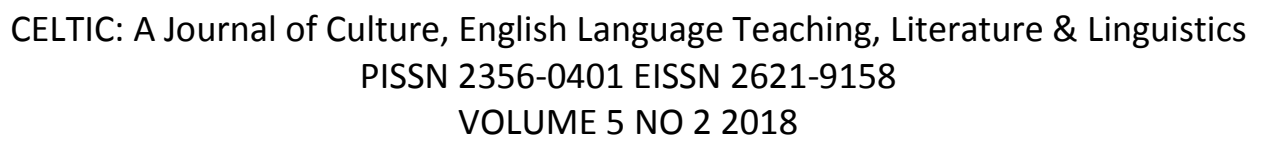


UMM. The discussion formulated 4 problems. Those are teacher's professionalism, student's motivation, the big number of students and student's English mastery. The first is teacher's professionalism. Most of the ESP teachers at UMM are fresh graduates who have less experience in teaching, commonly, they teach less than 5 years. The second is ESP is taught for all majors in UMM. There are plenty of students do not like learning English. Therefore, they have low motivation to participate in the learning process of ESP. the third is the number of students. Most of the classes in UMM have big number of students; one class consists of 40-50 students. The number of students can influence the learning process. It is required more attention from the teachers. The fourth is student's English mastery. In EFL country, the students have limitation of English understanding because English is only complementary subject for them. The 4 problems of ESP become the concern which must be solved with appropriate strategies. ESP problems in this context almost similarly happened in the other institutions (Nguyen, 2016). It means that identifying problem is the first stage before coming to the implementation LS (Salvador, 2017). It is a crucial part for LS process. LS must equip the students with solution for their learning problems (Druken, 2015).

The researcher managed Lesson Study workshop for ESP teachers. It is aimed to assist deep understanding to ESP teachers about LS. It is needed due to limited knowledge of LS for ESP teachers. The workshop was held for one day. The workshop provided explanation about history, purpose, and the steps of implementing LS.

The researcher formulated the LS team. There are 5 ESP teachers involved. This team was divided into different roles; one teacher as teacher model and the others as observers. The team was equipped from different length of teaching experience. The teacher model is a female fresh graduate who has been teaching for three months. It meant that she still has limited experience in teaching, mainly teaching ESP. Because she needs more experience in teaching, LS could give best practice of ESP teaching. Moreover, the two observers have been teaching ESP for two years, and the other have been teaching for seven years. These different backgrounds of teaching can facilitate the teachers transferring knowledge and experience among the team members.

The LS team decided major, subject, and class which would be implemented LS. The major was psychology, B class was taken. The LS team chose listening skill because listening skill was considered as the main concern in teaching ESP for psychology department. There were 55 students participated, 15 male students and 40 female students.

Planning stage is one of required phase in LS. Here would be embedded the problem that must be solved along the LS process(Appova, 2018; Bozkurt, 2018; Wahono, Perdana, Study, \& Pemula, n.d.), and goal is displayed which must be achieved in the learning process. LS program must meet these necessities (Ebaeguin, 2015; Had \& Jopling, 2016; Towaf, 2016). Planning is guidance for the LS team to acquire the successful of learning which could be as a typical principle for the teacher's development, the essence of the LS presence in teaching and learning.

\section{Implementation}

The implementation of LS was divided into two cycles with three phases in every cycle. The details would be explained as follows: 


\section{Cycle 1}

Step Plan

The LS team planed the teaching and learning process together. The Step Plan was divided into 4 stages. First, LS team figured the student's problems. Student's involvement identified as one of the problems which would be solved in cycle 1 . Second, LS team set the goals of the lesson. The goal is to make the students to be active in the class and participated in every learning process. Third, LS team constructed the activities which would be implemented in the class. The activities are divided into three stages; opening, main activity, and closing. The team administered Task Based Learning Method.

\section{Step Do}

The Ls team offered some approaches and techniques to solve the student's involvement problems. In apperception, LS team provides challenging activities by giving a case which is related to their daily life. For example, the LS team asked the students' experience having public transportation and the others must repeat what their friends said. Most of students encourage being apart in the activity. In main activity, LS team assists the students by interesting media, video to drag the student's attention on the activity. Then, the students are invited to list every new vocabulary they listen. Furthermore, the list must be shared to others and guess the meanings. Finally, the LS team ended the activity by giving main task which must be finished individually.

\section{Step See}

The learning process could be implemented well. The planned activity could be implemented $90 \%$. There were some planned activities not appeared in the learning process such as unclear instruction, sitting layout, and time management. However, the LS team could answer the student's involvement problems. Most of the students participated along the learning process.

One of the problems in this LS program was student's engagement. This LS could answer the problem. One of the benefits could be assisted in LS is a solution for the student's problem (Bjuland \& Mosvold, 2015). Moreover, LS could set the class atmosphere which was able to engage the students to participate in the learning process (Masyhud, 2018). However, cycle still found problems related to teacher's performance.

\section{Cycle 2}

\section{Step Plan}

The team constructed a plan based on the evaluation in cycle 1 . Thus, the team conducted similar phases in constructing the plan. It decided to apply method which focused on learner centre. The students were required actively involved along the learning process. Grouping and inquiry were administered as the techniques. Moreover, it modified the sitting layout in order to give a chance for passive students to take a part in the learning process.

\section{Step Do}

The teacher model started the class by asking the students the problems of their study, and the teacher model invited the students to give solution to their friend's problems. Furthermore, main activity was implemented by sharing teacher's model experience about her problems in study. On the other hand, students must give solution to their teacher's problems. They had various solutions, but only one solution would be

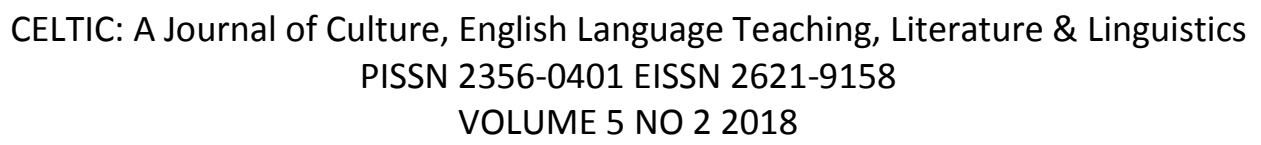


selected as the most appropriate with the teacher's problem. Grouping is the next part of student's activity. In grouping, they should make a story about student's problem. The story must be delivered to the other groups. On contrary, the other groups must listen carefully and note in detail what listen in order to give best solution for the group's problems offered. To make the students easily understand with the instruction, the team provided the instruction in the form of PowerPoint, so the students could read the instruction instead of listening from the teacher. Moreover, the teacher used L1 to make the student more understand the instruction. Finally, the students would simultaneously share and give solution to their friend's problems.

\section{Step See}

Along the learning process, it could be concluded that the students were really joyful with the activity in the class because they thought that the topic was quite closed with them. All students could involve in the learning process. The percentage of student's involvement is $95 \%$. Therefore, in cycle 2, the team could improve the problems in cycle 1 .

The use of L1 in ESP class is needed to help the students understand to the teacher's instruction because cycle one classified unclear instruction as a concern in which dominantly used English. Most of the students did not understand the instruction so that the LS team decided to use L1 in the class. The use of L1 in learning foreign language could accelerate the language mastery (Jin \& Cortazzi, 2018). Therefore, LS could facilitate teachers and students to solve their problems and develop their professionalism.

\section{REFERENCES}

Ahmadi, A., \& Rahimi, M. (2012). Barriers to English for specific purposes learning among Iranian University students. Procedia - Social and Behavioral Sciences, 47, 792-796. https://doi.org/10.1016/j.sbspro.2012.06.736

Appova, A. K. (2018). Engaging Prospective Elementary Teachers in Lesson Study. PRIMUS, O(0), 1-16. https://doi.org/10.1080/10511970.2017.1388311

Armstrong, A. (2011). Lesson study puts a collaborative lens on student learning. Tools For School, 14(4), 1-8. Retrieved from https://www.collaborativeclassroom.org/sites/default/files/media/pdfs/lessonstudy/l earning_forward.pdf\%5Cnwww.learningforward.org

Bjuland, R., \& Mosvold, R. (2015). Lesson study in teacher education: Learning from a challenging case. Teaching and Teacher Education, 52, 83-90. https://doi.org/10.1016/j.tate.2015.09.005

Bozkurt, E. (2018). Middle School Mathematics Teachers ' Reflection Activities in the Context of Lesson Study, 11(1), 379-394.

Cajkler, W., Wood, P., Norton, J., \& Pedder, D. (2013). Lesson Study: Towards a collaborative approach to learning in Initial Teacher Education? Cambridge Journal of Education, 43(4), 537-554. https://doi.org/10.1080/0305764X.2013.834037

Candel-mora, M. Á. (2015). Attitudes towards intercultural communicative competence of English for Specific Purposes students. Procedia - Social and Behavioral Sciences, 178(November 2014), 26-31.

CELTIC: A Journal of Culture, English Language Teaching, Literature \& Linguistics 
https://doi.org/10.1016/j.sbspro.2015.03.141

Druken, B. K. (2015). Teacher!Education!and!Knowledge:!Research!Reports! 663!!, 663-670.

Dudley, P. (2011). Lesson Study: a Handbook. Retrieved from http://lessonstudy.co.uk/wp-content/uploads/2012/03/Lesson_Study_Handbook_011011-1.pdf

Ebaeguin, M. (2015). Promoting Teacher Growth through Lesson Study: A Culturally Embedded Approach, 213-220.

Had, M., \& Jopling, M. (2016). Problematizing lesson study and its impacts : Studying a highly contextualised approach to professional learning, 60 . https://doi.org/10.1016/j.tate.2016.08.001

Hsu, L. (2014). Leisure , Sport \& Tourism Education Effectiveness of English for specific purposes courses for non-English speaking students of hospitality and tourism : A latent growth curve analysis. Journal of Hospitality, Leisure, Sport \& Tourism Education, 15, 50-57. https://doi.org/10.1016/j.jhlste.2014.05.001

Jin, L., \& Cortazzi, M. (2018). Use of the First Language, 1-7. https://doi.org/10.1002/9781118784235.eelt0203

Juwairiah. (2013). Professionalisme Guru melalui Lesson Study. Retrieved from http://sumut.kemenag.go.id/file/file/TULISANPENGAJAR/akzh134318323 $\underline{1 . p d f}$.

Kanauan, W., \& Inprasitha, N. (2014). Collaboration between Inservice Teachers and Student Intern in Thai Lesson Study. Procedia - Social and Behavioral Sciences, 116, 28-32. https://doi.org/10.1016/j.sbspro.2014.01.163

Masyhud. (2018). Lesson Study in Teaching Young Learners: Assisting a Dynamic Classroom Interaction, 11(1), 93-102.

Nguyen, C. D. (2016). Metaphors as a window into identity: A study of teachers of English to young learners in Vietnam. System, 60, 66-78. https://doi.org/10.1016/j.system.2016.06.004

Rahman, M. (2015). English for Specific Purposes ( ESP ): A Holistic Review, 3(1), 24-31. https://doi.org/10.13189/ujer.2015.030104

Saliu, B., \& Hajrullai, H. (2016). Best Practices in the English for Specific Purpose Classes at the Language Center. Procedia - Social and Behavioral Sciences, 232(April), 745-749. https://doi.org/10.1016/j.sbspro.2016.10.101

Salvador, A. C. (2017). The Potential of Lesson Study Project as a Tool for Dealing with Dilemmas in University Teaching, 7(2), 124-135. https://doi.org/https://doi.org/10.1108/IJLLS-12-2017-0056

Stigler, J.W. and Hiebert, J. (1999), the Teaching gap: Best idea from the world's teachers for

improving education in the classroom, Free Press, New York.

Towaf, S. M. (2016). Integration of Lesson Study in Teaching Practice of Social Study Student Teachers to Improve the Quality of Learning and Promote a Sustainable Lesson Study, 7(18), 83-91.

Wahono, B., Perdana, E., Study, L., \& Pemula, D. (n.d.). BERBASIS LESSON STUDY PADA PERKULIAHAN.

Ching-ning Chien., Margaretha Hsu. 2010: A case study of incorporating ESP instruction into the university English course. Shippensburg, Pennsylvania.

CELTIC: A Journal of Culture, English Language Teaching, Literature \& Linguistics 
Shippensburg University.

Suzini, S. M,. 2011. A Critical Review of the Current Situation of Teaching ESP in the Iranian Higher Education Institutions. The Iranian Journal. Vol. 7. No. 7. 